\section{Field Tests of Methanol as a Crop Yield Enhancer}

\author{
Milton E. McGiffen, Jr. ${ }^{1}$ and Robert L. Green \\ Department of Botany and Plant Sciences, University of California, Riverside, \\ CA 92521-0124
}

John A. Manthey

U.S. Citrus and Subtropical Products Laboratory, 600 Avenue S, North West, Winter Haven, FL 33881

\section{Ben A. Faber, A. James Downer, and Nicholas J. Sakovich University of California Cooperative Extension, 669 County Square Drive, Ventura, CA 93003}

\section{Jose Aguiar \\ University of California Cooperative Extension, 21150 Box Springs Road, Moreno Valley, CA 92557-8708 \\ Additional index words. carbon metabolism, gas exchange, photosynthesis, water stress, plant nutrition, plant growth regulators, crop productivity}

Abstract. To test the usefulness of methanol treatments in enhancing yield and drought tolerance, we applied methanol with and without nutrients to a wide range of crops across California: lemon (Citrus limon L.), creeping bentgrass (Agrotis palustris Huds.), romaine lettuce (Lactuca sativa L.), carrot (Daucus carota L.), corn (Zea mays L.), wheat (Triticum aestivum L.), pea (Pisum sativum L.), and radish (Raphanus sativus L.). Environments included greenhouse and field tests in coastal, inland-valley, and desert locations. Methanol did not increase the yield or growth of any crop. In some cases, methanol caused significant injury and decreased yield.

Benson (1951) found that algae could metabolize methanol for sugar and amino acid production as rapidly as $\mathrm{CO}_{2}$. From their field observations, Nonomura and Benson (1992a) concluded that foliar application increased turgidity via photorespiratory metabolism of methanol. The benefits of methanol applications were most evident under high photorespiration and presumably under increased capacity to metabolize methanol with minimal phytotoxicity. Adding nutrients to the spray solution enhanced the plant's ability to metabolize methanol. Glycine apparently increased the metabolism rate of methanol. Glycine was added to the spray solution to prevent injury at high methanol concentrations or when light intensity was reduced (Nonomura and Benson, 1992b). Repeated applications induced $\mathrm{N}$ deficiency, which was prevented by adding low-biuret urea to the methanol solution.

Received for publication 28 Dec. 1994. Accepted for publication 2 May 1995. Mention of a trademark or propriety does not constitute a guarantee or warranty of the product by the U.S. Dept. of Agriculture or the Univ. of California and does not imply its approval to the exclusion of other products that also may be suitable. The cost of publishing this paper was defrayed in part by the payment of page charges. Under postal regulations, this paper therefore must be hereby marked advertisement solely to indicate this fact.

${ }^{1}$ To whom reprint requests should be addressed.
Nonomura and Benson (1992a) reported large increases in growth and yield of a wide range of $\mathrm{C}_{3}$ species: tomato (Lycopersicon esculentum Mill.), 50\%; strawberry (Fragaria ×ananassa Duchesne), 60\%; eggplant (Solanum melongena L.), 60\%; cotton (Gossypium hirsutum L.), 50\%; savoy cabbage (Brassica oleracea L. Capitata Group), 50\%; wheat (Triticum aestivum L.), 100\%; rose (Rosa spp.), 40\%; palm (Washingtonia robusta $\mathrm{H}$. Wendl.), 70\%; and watermelon [Citrullus lanatus (Thunb.) Matsum \& Nakai], $36 \%$. Midday turgidity increased in most of those species. Methanol treatments decreased irrigation needs of cotton by $50 \%$; savoy cabbage produced thicker, larger leaves; and roses bloomed 5 to 10 days earlier. $\mathrm{C}_{4}$ species, which have minimal photorespiration, were unaffected.

The mass media began suggesting foliar methanol treatments as a solution to world hunger, especially in arid regions (Dye, 1993). There was great interest among plant science researchers, and many groups began laboratory and field experiments. However, experimental results have been mixed. Devlin et al. (1994) and Nishio et al. (1993) found yield increases from methanol applications in controlled environments. Preliminary field experiments with California vegetables failed to demonstrate yield increases from methanol treatments (Hartz et al., 1994). There have been several recent abstracts on the effect of methanol on the growth of a wide range of crops, but most data rejected methanol as a yield enhancer (Dami et al., 1994; McGiffen et al., 1994; Valenzuela et al., 1994; Wutscher, 1994). Nevertheless, reports on using methanol to increase crop yields continue to appear in the popular media, and the approach has been incorporated into an undergraduate textbook (Chrispeels, 1994). A company has begun to sell ready-to-use spray bottles of methanol solution (MegaBoost; Primary Products, Woburn, Mass.). The Environmental Protection Agency (EPA) has ruled that methanol is a plant nutrient and not subject to the more stringent regulations that apply to plant growth regulators (EPA Press Release, 19 Mar. 1993).

To determine the benefit of foliar methanol applications in agricultural production, we conducted a series of experiments, which closely followed Nonomura and Benson's (1992a) methods, in coastal, inland-valley, greenhouse, and desert locations during the summer and winter seasons. The range of environments and plant species were selected to ensure thorough testing of the effectiveness of methanol in a wide array of agricultural situations. Although the locations were widely separated, they all shared the southwestern North America climate of low humidity, intense solar radiation, and temperatures $>30 \mathrm{C}$ that Nonomura and Benson (1992a) reported as most favorable for yield increases with methanol treatments.

\section{Materials and Methods}

Coastal lemons. Two separate experiments were conducted on 1-year-old, containergrown 'Eureka' lemon (grafted on Carrizo Citrange rootstock) in a nursery in Saticoy, Calif. The trees were grown in 19-liter pots filled with a 1 silt-loam soil : 1 wood shavings : 1 mushroom-bedding compost mixture (by volume). The potting mix was sterilized by fumigation for $48 \mathrm{~h}$ with methyl bromide. In the single-application experiment, methanol was applied one time at the initiation of the trial; the multiple-application experiment received five methanol applications at 18-day intervals. Both experiments used a randomized complete-block design with 10 replications and the following six treatments: $0 \%$, $5 \%, 10 \%, 20 \%, 40 \%$, and $80 \%(\mathrm{v} / \mathrm{v})$ methanol solutions. The solutions also included $0.1 \%$ Tween $80(\mathrm{v} / \mathrm{v})$ as a surfactant but no urea or glycine. All applications were made with a hand-held sprayer to runoff. Tree height and leaf counts were taken at each application interval and the end of the trial. Applications were made at 13:00 $\mathrm{HR}$ when temperatures were $>32$ C. During each irrigation, a complete nutrient solution containing $111 \mathrm{mg} \mathrm{N} / \mathrm{liter}$ and $48 \mathrm{mg} \mathrm{K} / \mathrm{liter}$ was applied uniformly to all trees by fertigation. Supplemental $\mathrm{P}$ was added to the potting soil at planting. Treatments were initiated 21 May and completed 26 Aug. 1993.

Desert turfgrass. Three separate experiments were conducted on a creeping bentgrass ('Penncross') putting green in Rancho Mirage, Calif. The root-zone construction was typical of a U.S. Golf Association-type putting green. The bentgrass was seeded in Jan. 1993. During our study, the putting green was 
mowed every other day at a 5-mm cutting height, fertilized with Milorganite $(6.0 \mathrm{~N}-1.7 \mathrm{P}-$ $0 \mathrm{~K})$ at a rate of $1.47 \mathrm{~g} \mathrm{~N} / \mathrm{m}^{2}$ every 3 weeks, and irrigated to prevent visual drought symptoms ( $\approx 20 \mathrm{~mm} /$ week $)$.

This study consisted of three separate experiments during consecutive months in Summer 1993. Each experiment used a progressively higher concentration of methanol: $16 \%$, $26 \%$, and $42 \%(\mathrm{v} / \mathrm{v})$ of spray volume; for the latter two, we used a control treatment of nutrients and water. We used a nontreated control to compare with $16 \%$ methanol. The $16 \%$ methanol solution was applied on $7 \mathrm{July}$, $26 \%$ on 5 Aug., and $42 \%$ on 9 Sept. All solutions contained $1 \%$ low-biuret urea (v/v), $0.08 \% \operatorname{Fe} \operatorname{EDTA}(0.8 \mathrm{w} / \mathrm{v}), 0.1 \%$ surfactant $(\mathrm{v} /$ $\mathrm{v}$, Triton AG 98$)$, and $0.1 \%$ glycine $(1 \mathrm{w} / \mathrm{v})$ (Nonomura and Benson, 1992b). Solutions were applied with a Cushman-Broyhill golf course sprayer using a spray volume of 407 liters $\cdot \mathrm{ha}^{-1}$.

Individual plots were $2.03 \times 15.24 \mathrm{~m}$. There were four replications of each treatment arranged in a randomized complete-block design. Methanol-treated and nontreated plots remained at the same location during the three trials.

In each trial, clipping yields from 2 days of growth were collected from each entire plot 1 and 2 weeks following treatment applications. Clippings were dried at $40 \mathrm{C}$ for $48 \mathrm{~h}$ and then weighed. Visual inspection of the plots during each trial indicated that there was no phototoxicity due to any of the treatments.

Low-desert vegetables. All experiments were conducted near Indio, Calif., using standard fertility and pest management practices. Sprinkler irrigation was used for the first 2 weeks after planting to establish both crops, then crops were watered by furrow for the remainder of the season. Romaine lettuce ('Paris Island Cos') was transplanted 3 Oct. 1993 on an Indio very fine sandy loam. Carrots ('Apache') were direct-seeded 10 Sept. 1993 on a Gilman fine sandy loam. Both crops were planted on 110-cm (center to center) beds. Lettuce was planted in a single row that was thinned to $20 \mathrm{~cm}$ between plants. Each bed of carrots had six rows arranged as two sets of three rows each, with each three-row set on the bed shoulder $10 \mathrm{~cm}$ from the edge of the bed; the three rows within a set were $4 \mathrm{~cm}$ apart.

Table 1. Yield of romaine lettuce treated with methanol in field experiments in the low desert near Indio, Calif.

\begin{tabular}{|c|c|}
\hline $\begin{array}{l}\text { Methanol } \\
\text { concn }(\%)\end{array}$ & $\begin{array}{c}\text { Yield } \\
\left(\mathrm{kg} \cdot \mathrm{m}^{-2}\right)\end{array}$ \\
\hline 0 (water only) ${ }^{2}$ & $9.99 \mathrm{a}^{\mathrm{y}}$ \\
\hline 0 (nutrients only) ${ }^{2}$ & $10.31 \mathrm{a}$ \\
\hline 10 & $8.93 \mathrm{~b}$ \\
\hline $30^{x}$ & $8.82 \mathrm{~b}$ \\
\hline
\end{tabular}

${ }^{2}$ The methanol and nutrients only treatments included $0.1 \%$ surfactant, $0.08 \%$ Fe EDTA, and $0.1 \%$ glycine in the spray solution.

'Mean separation by Duncan's multiple range test $(P<0.05)$.

${ }^{x}$ Foliar injury to the lettuce was apparent after the first 30\% methanol application. Therefore, we subsequently used a $10 \%$ methanol solution.
Beginning on 15 Oct., both crops received weekly foliar treatments of the following solutions: distilled water only; water, $0.1 \%$ surfac$\operatorname{tant}(\mathrm{v} / \mathrm{v})($ Kinetic, Setre Chemical Co., Mem- phis, Tenn.), $0.08 \%$ Fe EDTA (0.8 w/v), and $0.1 \%$ glycine $(1 \mathrm{w} / \mathrm{v})$; and methanol mixed with the previous nutrient solution. Methanol solutions of $10 \%$ and $30 \%(\mathrm{v} / \mathrm{v})$ were applied
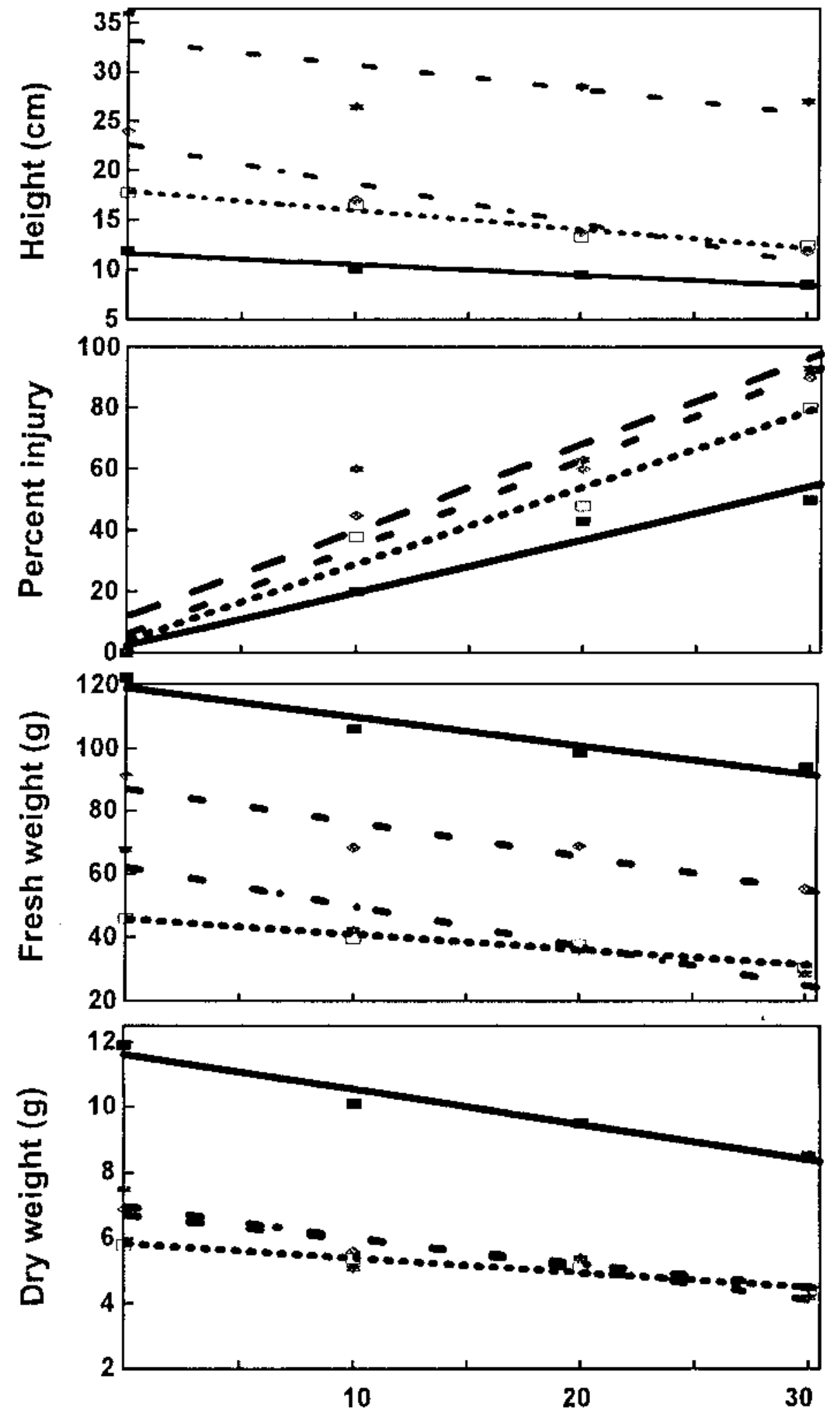

\section{Percent methanol applied}

Fig. 1. Response of $(\diamond)$ corn, $(\boldsymbol{\square})$ radish, $(-\bullet-)$ pea, and $(\square)$ wheat to methanol. All plants received two weekly applications of a 5-ml methanol solution and $0.2 \%$ glycine in distilled water. Percent injury was determined as visual evaluation of foliage immediately before harvest using a 0 to 100 rating scale, where $0=$ no injury, $100=$ complete necrosis. 
to the romaine lettuce, but carrots received only $30 \%$. A randomized complete-block design with four replications was used. Plots were $3 \mathrm{~m}$ long for carrots and $10 \mathrm{~m}$ long for lettuce. Foliage was sprayed until completely saturated and solution began to runoff. Carrots received a total of five weekly applications. In lettuce, foliar injury was apparent after the first application of $30 \%$ methanol; subsequently, we used only $10 \%$. Romaine lettuce and carrots were harvested on 23 Nov. and 23 Dec. 1993, respectively. Lettuce chlorophyll content was estimated at harvest using a chlorophyll meter (model SPAD-502; Minolta Camera Co., Japan). A rosette leaf from each of 15 plants from each plot was measured for greenness and then correlated with leaf chlorophyll content (Marquard and Tipton, 1987; Yadava, 1986).

Greenhouse experiments. Greenhouses at the Citrus Research Center in Riverside, $\mathrm{Ca}$ lif., were maintained at $25 \pm 5 \mathrm{C}$. Seeds of corn ('Landmark'), wheat ('Yecora Roja'), pea ('Little Marvel'), and radish ('Early Scarlet Globe') were sown in 1-liter pots filled with a 1 sand : 1 peatmoss mixture $(\mathrm{v} / \mathrm{v})$. All treatments were replicated four times in a randomized complete-block design and fertilized weekly with Hoagland's solution. One week after emergence, plants were thinned to 10 plants per pot. Methanol applications were made as per the protocol of Devlin et al. (1994). An atomizer applied $5 \mathrm{ml}$ of a mixture of methanol, water, and $0.2 \%$ glycine $(2 \mathrm{w} / \mathrm{v})$ to each pot. Treatments were methanol at $0 \%$, $10 \%, 20 \%$, and $30 \%(\mathrm{v} / \mathrm{v})$ of the total solution. Radish seedlings were sprayed with methanol 14 and 21 days after planting and were harvested on day 27 . Wheat seedlings were sprayed 7 and 14 days after planting and were harvested on day 26. Methanol was applied to pea and corn seedlings 7 and 14 days after planting, and plants were harvested on day 21 . Percent injury over each entire pot was determined as visual evaluation of foliage immediately before harvest using a 0 to 100 rating scale, where $0=$ no injury and $100=$ necrosis of the entire plant. Shoot length, root length, fresh weight, and dry weight were determined at harvest, and all data were averaged for the 10 plants in each pot. The experiment was repeated 1 month later. The data from both runs of the experiment were combined and analyzed as a split-plot design with experiment as the subplot effect. There was no treatment $\times$ experiment interaction, so the means from both experiment dates were averaged.

\section{Results and Discussion}

Coastal lemons. The multiple and single methanol application experiments with lemon were statistically equivalent $(P<0.001)$. Lemon tree height and number of leaves progressed normally and growth accelerated after 30 days. The number of leaves per tree increased from an average of 25 at the start of the study to 80 leaves per tree 140 days later but was unaffected by any treatment at any rating date. Lemons are one of the fastest-growing citrus trees. All trees grew more than $70 \mathrm{~cm}$ during the study, regardless of methanol concentration. However, lemons tolerated methanol concentrations $\leq 80 \%$ without negatively affecting growth. Lemons were well-watered and grown in coastal California; thus, photorespiration may have been low.

Desert turfgrass. Creeping bentgrass was grown in the low-desert summer climate of intense sun and daytime temperatures $>45 \mathrm{C}$. High rates of photorespiration often inhibit the growth of putting greens. Clipping yields 2 weeks after treatment from the experiments conducted in September were generally lower $\left(\approx 0.8 \mathrm{~g} \cdot \mathrm{m}^{-2}\right)$ than those in July and Aug. (1.3 to $\left.1.5 \mathrm{~g} \cdot \mathrm{m}^{-2}\right)$. However, no methanol treatment affected bentgrass yield. Foliar injury was absent. Because methanol can act as a solvent for many biologically active compounds, these results suggest the potential use of methanol as a carrier for applications of substances with low water solubility.

Low-desert vegetables. Lettuce and carrots were grown in the low-desert fall climate of sunny days and daytime highs of 30 to $35 \mathrm{C}$. Lettuce yields were reduced similarly by $10 \%$ and $30 \%$ methanol (Table 1 ). The $30 \%$ methanol treatment induced moderate levels of phytotoxicity in the new growth that followed the initial application. Chlorosis of the leaves became evident shortly after treatment, although the yellowing was not visible at harvest. Leaf chlorophyll measurements made at harvest indicated no treatment differences. Chlorosis was never apparent in carrots, and yield was unaffected by any treatment (range, 4.6 to 4.9 $\left.\mathrm{kg} \cdot \mathrm{m}^{-2}\right)$.

Greenhouse experiments. The greenhouse experiments consistently found a correlation between methanol concentration, a decline in growth, and a rise in foliar injury (Fig. 1, Table 2 ). The $r^{2}$ for growth characteristics regressed against the percentage of methanol applied $>0.78$ for all regressions, except height in pea (Table 2). The vining growth habit of peas may be the reason that vertical height was less responsive to methanol injury than in the other species. Wheat lost the most height relative to the control and showed the most visible injury. However, increasing methanol concentration affected wheat fresh and dry weight less than for the other species. Pea had the sharpest decline in fresh weight, with radish and corn showing a similar pattern. Pea and corn lost a similar percentage of dry weight as methanol concentration increased. Methanol caused less foliar injury in corn than any other species (Fig. 1). This result conflicts with Nonomura and Benson's (1992a) report that $\mathrm{C}_{4}$ species do not metabolize methanol and are more susceptible to injury. All the growth criteria measured indicate that methanol was not used to enhance growth but rather injured $\mathrm{C}_{3}$ (radish, wheat, and pea), as it did $\mathrm{C}_{4}$ (corn) species.

Our experiments included eight plant species grown in four distinctive locations. We found no indications that methanol increases yield or growth. The greenhouse and lowdesert romaine lettuce experiments had dramatic visual injury symptoms and yield reductions from methanol treatments. Every effort was made to follow the protocols from previous studies that reported growth and yield increases from methanol. Indeed, application procedures, such as adding nutrients and surfactants in spray solutions and the volume of application, varied among our experiments in an effort to duplicate previous procedures and results. Variations in the scheme for foliar application seem to have had no effect on results. Methanol may be suitable as a carrier for products with low water solubility but should not be recommended as an enhancer of crop yield or growth.

\section{Literature Cited}

Benson, A.A. 1951. Identification of $\mathrm{C}^{14} \mathrm{O}_{2}$ photosynthetic products. J. Amer. Chem. Soc. 73:2971.

Chrispeels, M.J. 1994. Plants, genes, and agriculture. Jones and Bartlett Publishers, Boston.

Dami, I., C. Stushnoff, and R. Hamman. 1994. Physiological and biochemical responses of grapevines to methanol. HortScience 29:441.

Devlin, R.M.,P.C. Bhomik, and S.J. Karczmarczyk. 1994. Influence of methanol on plant germina-

Table 2. Regression coefficients and $r^{2}$ for greenhouse applications of foliar methanol solutions. All plants received two weekly applications of a 5-ml solution of methanol and $0.2 \%$ glycine in distilled water.

\begin{tabular}{llcrc}
\hline \hline $\begin{array}{l}\text { Growth } \\
\text { characteristic }\end{array}$ & Crop & $r^{2}$ & $\mathrm{a}$ & $\mathrm{b}$ \\
\hline Height $(\mathrm{cm})$ & Corn & 0.95 & $11.62 \mathrm{a}^{2}$ & $-0.108 \mathrm{a}$ \\
& Radish & 0.93 & $6.71 \mathrm{a}$ & $-0.070 \mathrm{a}$ \\
& Pea & 0.53 & $33.25 \mathrm{c}$ & $-0.250 \mathrm{~b}$ \\
& Wheat & 0.98 & $26.67 \mathrm{c}$ & $-0.260 \mathrm{~b}$ \\
Fresh weight (g) & Corn & 0.93 & $119.39 \mathrm{a}$ & $-0.921 \mathrm{a}$ \\
& Radish & 0.86 & $87.25 \mathrm{~b}$ & $-1.075 \mathrm{a}$ \\
& Pea & 0.88 & $62.26 \mathrm{c}$ & $-1.244 \mathrm{~b}$ \\
& Wheat & 0.95 & $45.92 \mathrm{~d}$ & $-0.498 \mathrm{c}$ \\
Dry weight (g) & Corn & 0.95 & $11.62 \mathrm{a}$ & $-0.108 \mathrm{a}$ \\
& Radish & 0.93 & $6.71 \mathrm{~b}$ & $-0.074 \mathrm{~b}$ \\
& Pea & 0.79 & $6.99 \mathrm{~b}$ & $-0.096 \mathrm{a}$ \\
& Wheat & 0.97 & $5.85 \mathrm{c}$ & $-0.045 \mathrm{c}$ \\
Injury $(\%)$ & Corn & 0.96 & $2.30 \mathrm{a}$ & $1.730 \mathrm{a}$ \\
& Radish & 0.96 & $6.00 \mathrm{a}$ & $2.850 \mathrm{~b}$ \\
& Pea & 0.87 & $11.70 \mathrm{a}$ & $2.820 \mathrm{~b}$ \\
& Wheat & 0.96 & $4.00 \mathrm{a}$ & $2.500 \mathrm{~b}$ \\
\hline
\end{tabular}

${ }^{2}$ Mean separation in rows for each crop and variable by Duncan's multiple range test at $P<0.05$. Data are the average of 10 plants in each replicate. Mean separation is not applicable to the $r^{2}$ statistic.

'Percent injury was determined as visual evaluation of foliage immediately before harvest using a 0 to 100 rating scale, where $0=$ no injury and $100=$ necrosis of the entire plant. 


\section{Crop Production}

tion and growth. Plant Growth Soc. Amer. Quarterly 22:102-108.

Dye, L. 1993. Methanol is embraced as a crop aid. Los Angeles Times 4 Apr. 1993.

Hartz, T.K., K.S. Mayberry, M.E. McGiffen, Jr., M. LeStrange, G. Miyao, and A. Baameur. 1994. Foliar methanol application ineffective in tomato and melon. HortScience 29:1087.

Marquard, R.D. and J.L. Tipton. 1987. Relationship between extractable chlorophyll and an in situ method to estimate leaf greenness. HortScience 22:1327.

McGiffen, M.E., J. Manthey, A. Baameur, R.L.
Green, B.A. Faber, A.J. Downer, and J. Aguiar. 1994. Field tests of methanol as a crop yield enhancer. HortScience 29:459.

Nishio, J.N., S. Huang, T.L. Winder, M.P. Brownson, and L. Ngo. 1993. Physiological aspects of methanol feeding to higher plants, p. 8-13. In: Proc. 20th Annu. Mtg. Plant Growth Regulat. Soc. Amer., 6-9 Aug. 1993, St. Louis.

Nonomura, A.M. and A.A. Benson. 1992a. The path of carbon in photosynthesis: Improved crop yields with methanol. Proc. Natl. Acad. Sci. USA 89:9794-9798.

Nonomura, A.M. and A.A. Benson. 1992b. The path of carbon in photosynthesis: Methanol and light, p. 911-914. In: N. Murata (ed.). Research in photosynthesis. Kluwer Academic Publ., Dordrecht, The Netherlands.

Valenzuela, H.R., O. Kawabata, and H. Yamamoto. 1994. Effect of methanol on biomass accumulation and photosynthetic efficiency of vegetable crops in Hawaii. HortScience 29:510.

Wutscher, H. 1994. The effect of methanol on orange fruit quality. HortScience 29:575.

Yadava, U.L. 1986. A rapid nondestructive method to determine chlorophyll in intact leaves. HortScience 21:1449-1450. 